1 Highlights:

2

- Summary of IgE, IgE receptor and anti-lgE crystal structures

- Comparison of anti-lgE treatment approaches and modes of action

4

- Classification of disruptive lgE inhibitors

5

- Suggestion of multi-level targeting concept using disruptive IgE inhibitors 


\section{Targeting IgE in allergic disease}

3

4 Pascal Gasser ${ }^{1,2}$ \& Alexander Eggel ${ }^{1,2}$

5

$6 \quad{ }^{1}$ Department of BioMedical Research, University of Bern, Bern, Switzerland

$7 \quad{ }^{2}$ Department of Rheumatology, Immunology and Allergology, University Hospital Bern,

8 Bern, Switzerland

9

10 Corresponding author: Alexander Eggel, Department of RIA, University of Bern,

11 Switzerland. Phone: +41 3163222 87, E-mail: alexander.eggel@dbmr.unibe.ch.

12

13

14 


\section{Abstract}

16 Immunoglobulin $\mathrm{E}(\mathrm{IgE})$ represents the least abundant antibody isotype in human

17 serum. Nevertheless, it has the ability to induce remarkably potent allergic reactions.

18 As a key component in the development and manifestation of hypersensitivity

19 responses against usually non-hazardous foreign substances, IgE has become a 20 major target of investigation and the subject of multiple therapeutic approaches for the

21 treatment of allergies. Recent advances in the understanding of pathophysiologic

22 mechanisms underlying IgE-associated allergic disorders have led to the generation

23 of new drug candidates that are currently in development or under clinical evaluation.

24 In this review, we highlight molecular and structural mechanisms underlying the

25 different anti-IgE molecules and suggest a concept of multi-level targeting using a new

26 class of disruptive IgE inhibitors to potentially optimize treatment efficacy. 


\section{Introduction}

Since its discovery little more than 50 years ago, immunoglobulin $\mathrm{E}(\lg E)$ has been attributed a wide variety of immunological functions including host defense against parasite infections and toxic venoms [1-3]. It has become increasingly evident that besides these beneficial properties $\lg \mathrm{E}$ is a central player in the development and manifestation of allergic reactions [4]. Allergic rhinoconjunctivitis, atopic dermatitis, food allergies or allergic asthma are mostly IgE-dependent allergic conditions which manifest in symptoms ranging from mild local reactions to life-threatening systemic episodes. Generally, allergies are causing a marked reduction in quality of life and due to the low cost-effectiveness of targeted anti-IgE intervention strategies patients are often treated with unspecific therapeutics such as corticosteroids $[5,6]$. Recent advances in the understanding of basic molecular and structural properties of $\lg E$ and its receptors have helped to develop more targeted treatment approaches (Table 1) that we highlight in this review.

\section{Structure-function relationship in IgE and its receptors}

As a heterodimeric glycoprotein IgE consists of two light and two heavy chains. The heavy chain Fc-region of $\lg E(\operatorname{IgE}-\mathrm{Fc})$ contains three consecutive Ig-domains, termed

Cع2-4 (Figure 1a). Compared to other immunoglobulins it lacks a flexible hinge region and thus adopts a rigid bent conformation in solution in which the $C \varepsilon 2$ domain of both heavy chains asymmetrically fold back onto the C\&3 domain [7]. IgE exerts its effector functions through mutually exclusive interactions with its two principal cell surface receptors FcERI and CD23 [8].

The high-affinity $\lg E$ receptor $F c \varepsilon R I$ is expressed as an $\alpha \beta \gamma_{2}$ heterotetramer primarily on human basophils and mast cells and as an $\alpha \gamma_{2}$ heterotrimer on human dendritic cells and monocytes [9]. FcERla binds IgE-Fc via two distinct interaction-sites [10]. 
53 While the $\mathrm{C} \varepsilon 3$ domains are in direct contact with the receptor, the $C \varepsilon 4$ domains form a 54 heavy chain dimerization interface. The 1:1 complex between IgE and FceRla is of remarkably high affinity $\left(K_{D} \sim 10^{-9}-10^{-10} \mathrm{M}\right)$. Crystallization experiments have revealed that IgE undergoes a large conformational change upon FceRla binding in which the Cع3:C\&4 interdomain angle significantly increases (Figure 1b) [11]. This FceRlabound IgE-Fc arrangement is referred to as open conformation (Figure 1c) [10,12].

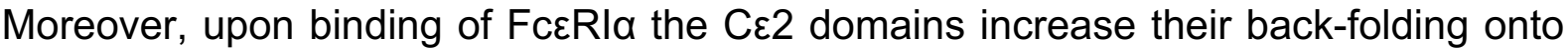
the $\mathrm{C} \varepsilon 3$ domain which further aggravates the asymmetrically bent conformation of $\lg E$ (Figure 1d) [11]. Interestingly, the C\&2 domains are not necessary for FceRla binding, but slow down both on and off rates for FcERla engagement [13]. Functionally, allergen induced cross-linking of FcERI-bound IgE stimulates degranulation of basophils and mast cells that results in the release of pre-stored as well as de novo synthesized proinflammatory and vasoactive mediators inducing classical symptoms of an allergic disorder [14].

The second $\lg E$ cell surface receptor is CD23. Due to its carbohydrate binding head domain, it belongs to the C-type lectin superfamily [15]. Even though $\lg E$ is one of the most glycosylated mammalian immunoglobulins, binding to CD23 has been shown to be independent of lectin-glycan interactions $[16,17]$. Since monomeric IgE:CD23 complexes are typically unstable $\left(\mathrm{K}_{\mathrm{D}} \sim 10^{-6}-10^{-7} \mathrm{M}\right) \mathrm{CD} 23$ is also referred to as lowaffinity $\lg E$ receptor [18]. The presence of $\mathrm{Ca}^{2+}$ substantially enhances the affinity for IgE about 30-fold through the induction of conformational changes in the receptor $[19,20]$. Crystal structures have revealed that binding of IgE occurs via the CD23 head domain in a 2:1 stoichiometry (Figure 1e) $[8,21]$. A study using negative stain electron microscopy has recently described an additional contribution of the CD23 stalk region to $\lg E$ binding [22]. Given the asymmetric bent conformation of $\lg E$, it has been reported that the two CD23 interaction sites have different binding kinetics and affinities 
Gasser et al.

79 [21]. Upon CD23 binding the IgE-Fc adopts a closed conformation in which the Cع3-

$\mathrm{C} \varepsilon 4$ interdomain angle significantly decreases (Figure 1f). CD23 is mainly expressed on B-cells, epithelial cells as well as antigen-presenting cells and multiple studies have highlighted the role of CD23 in the regulation of IgE synthesis as well as allergen transport and presentation [23,24].

\section{Classical inhibition of free serum IgE}

Omalizumab, also known as Xolair $^{\circledR}$, is a humanized monoclonal anti-lgE antibody that has initially been approved for the treatment of moderate to severe persistent allergic asthma [25] including children $\geq 6$ years of age [26]. More recently, it has been authorized for the use in patients with chronic spontaneous urticaria [27]. Additionally, off-label use of Omalizumab has revealed its efficacy in facilitating allergen updosing and desensitization in allergen-specific immunotherapy $[28,29]$. Omalizumab binds IgE with high affinity $\left(\mathrm{K}_{\mathrm{D}} \sim 7 \times 10^{-9} \mathrm{M}\right)[30]$. Its primary mode of action is the neutralization and clearance of free serum IgE which further results in the destabilization and loss of FceRI on mast cells and basophils [31]. Interestingly, treatment with Omalizumab has also been shown to reduce the number of circulating basophils [32]. Crystal structures of Omalizumab with a closed conformation IgE-G335C-Fc $\mathrm{F}_{3-4}$ mutant helped to precisely map the binding-site of Omalizumab to the $\mathrm{C} \varepsilon 3$ domain of IgE (Figure 1g) and revealed that the inhibition of $\lg E$ binding to $F c \varepsilon R I$ is due to steric conflicts of the Omalizumab light-chain with FceRla, while there is barely any direct competition for FcERla binding residues [33]. An alternative possibility of Omalizumab-mediated inhibition of IgE:Fc\&RI complex formation has recently been suggested [34]. The authors of this study propose an allosteric mechanism in which Omalizumab binding induces an unbending of $\lg E$ that is associated with structural changes compromising FceRI binding. Both studies agree that Omalizumab prevents binding of IgE to CD23, 
105 which is dependent on direct competition for receptor-binding residues on IgE as well as major steric clashes between CD23 and Omalizumab [33]. Even though a recent study has reported that CD23 surface levels on B-cells of allergic patients correlate with allergen-specific IgE levels it remains elusive whether Omalizumab treatment has a direct effect on IgE-production in B-cells through inhibition of $\lg E$ :CD23 interaction [35].

QGE031, also known as Ligelizumab, is a humanized high-affinity anti-lgE antibody that is based on the previously developed CGP51901 antibody (i.e. Talizumab or TNX901). Compared to Omalizumab, Ligelizumab binds IgE with significantly higher affinity $\left(K_{D} \sim 1.4 \times 10^{-10} M\right)$ and suppresses $\lg E$ serum levels with six- to nine-fold higher potency [30]. Further, the reduction of cell surface IgE on circulating basophils is more sustained and the inhibition of skin prick responses to allergens is more pronounced upon Ligelizumab treatment. Despite promising results in a phase I study with mild allergic asthma patients (NCT01703312) [36], the phase 2 study with asthma patients (NCT02336425) has been discontinued. A phase 2b study, testing the efficacy and safety of Ligelizumab in patients with chronic spontaneous urticaria has recently been completed (NCT02477332) and results are pending.

Another anti-IgE antibody, called MEDI4212, has been engineered from a single-chain variable fragment selected against IgE using phage display [37]. It binds IgE with even higher affinity than Ligelizumab $\left(\mathrm{K}_{\mathrm{D}} \sim 2 \times 10^{-12} \mathrm{M}\right)$ and also inhibits binding to FceRla [37]. Further, MEDI4212 has been shown to inhibit IgE binding to CD23 on B-cells in vitro. Crystal structures of MEDI4212 in complex with $\operatorname{lgE}-\mathrm{Fc}_{3-4}$ helped to map its interaction-site to the $\mathrm{C}_{\varepsilon} 3$ domain of $\lg \mathrm{E}$ and showed that it directly competes with FceRla but not CD23 binding residues on IgE (Figure 1h). This study suggests that MEDI4212 locks IgE in an open conformation which is unable to bind CD23 [37]. In a Phase 1 clinical trial (NCT01544348) MEDI4212 showed superior results in 
131 suppressing IgE levels compared to Omalizumab [38]. However, IgE levels returned 132 to baseline faster in MEDI4212 treated patients, which might be due to its shorter 133 serum half-life.

\section{Targeting IgE producing B cells}

136 Cross-linking of the B-cell receptor (BCR) without co-stimulation has been reported to 137 induce apoptosis [39]. To exploit this mechanism and to test whether targeting and

138 depletion of IgE producing B-cells might represent a suitable therapeutic strategy to 139 decrease serum IgE levels an antibody specific for the membrane proximal domain 140 (M1) of the IgE BCR has been developed [40]. This antibody, initially termed 47H4, 141 successfully reduced the number of IgE expressing B-cells and decreased serum $\lg E$ 142 levels in mice. Since afucosylation of antibodies increases their affinity to FcyRIIIA on 143 NK-cells and thereby enhances the potentcy of antibody dependent cellular cytotoxicity 144 (ADCC) a humanized, afucosylted version of $47 \mathrm{H} 4$, called Quilizumab, has been 145 generated and tested in humans with allergic conditions. Quilizumab treatment of 146 patients with allergic rhinitis and mild allergic asthma reduced baseline allergen147 specific and total $\lg E$ in serum up to $30 \%$ in a phase $1 \mathrm{~b}$ (NCT01160861) and 2a 148 (NCT01196039) clinical trial [41]. These reductions were sustained for at least 6 149 months. While a significant amelioration of the allergen-induced symptoms in the early150 asthmatic response to airway challenge was observed, no improvement was apparent

151 for the late asthmatic response. In another phase 2 study in adults with inadequately 152 controlled asthma (NCT01582503) no clinical significant improvement was achieved 153 upon Quilizumab treatment [42]. Moreover, an additional phase 2 study in adults with 154 refractory chronic spontaneous urticaria (NCT01987947) failed to demonstrate 155 significant clinical efficacy of Quilizumab [43]. 
156 Recently, modified versions of the monoclonal anti-IgE antibody MEDI4212 with

157 improved binding to FcyRIIIA have been engineered. While the reactivity against IgE

158 remained unchanged the elimination of $\mathrm{IgE}$ expressing B-cells in vitro was significantly

159 increased [44]. The afucosylated variant of MEDI4212 decreased serum IgE levels in 160 a humanized mouse model to a higher degree than the fucosylated variant [44]. No

161 clinical human data is currently available for the afucosylated variant of MEDI4212.

162

\section{Disruptive IgE inhibitors - a new class of anti-IgE molecules}

164 In 2012, a new and promising class of anti-lgE molecules with the ability to not only 165 neutralize free $\lg \mathrm{E}$ but in addition actively dissociate pre-formed $\lg \mathrm{E}: \mathrm{FcER}$ complexes 166 has been reported $[45,46]$. The disruptive IgE inhibitor, termed DARPin ${ }^{\circledR}$ E2_79, and 167 its improved bivalent version, DARPin ${ }^{\circledR}$ bi53_79, have been demonstrated to 168 desensitize allergic effector cells by actively removing IgE from their cell surface [47].

169 This mechanism - termed facilitated dissociation - differs from the classic competitive 170 and the allosteric inhibition model [48]. It represents a competitor-induced dissociation

171 mechanism in which the binding site on a ligand becomes exposed during partial 172 ligand:receptor complex dissociation [46]. Interestingly, it has been shown in these 173 studies that Omalizumab also accelerates the dissociation of IgE:FcERI - however, only 174 at very high concentrations [47]. Recently, the disruptive activity of Omalizumab has 175 been enhanced by introducing three point-mutation into the variable light and constant 176 domain of its Fab fragment, called FabXol3 [34]. The binding sites of FabXol3 and 177 DARPin ${ }^{\circledR}$ E2_79 on the $\mathrm{C} \varepsilon 3$ domain of $\lg E$ are overlapping and of similar size (Figure 178 1I, J). While E2_79 is acting through facilitated dissociation [46], an allosteric 179 mechanism has been proposed for FabXol3 [34].

180 Further, a llama-derived humanized single-domain antibody, named 026 sdab, has 181 been described to inhibit IgE binding to Fc\&RI through an allosteric mechanism by 
182 trapping IgE in a closed conformation [49]. The crystal structure of 026 sdab with lgE$183 \mathrm{FC}_{3-4}$ revealed no overlap with $\mathrm{Fc \varepsilon RI}$ binding sites but significant competition with CD23 184 attachment points on $\lg E$. 026 sdab binds $\lg E$ with high affinity $\left(K_{D} \sim 1.4 \times 10^{-9} M\right)$ and 185 has the ability to disrupt pre-formed IgE:FcERI complexes (Figure 1k). In line with the 186 observed removal of surface $\operatorname{lgE}, 026$ sdab decreased basophil allergen-sensitivity. 187 Furthermore, 026 sdab has been shown to inhibit binding of IgE:allergen complexes to 188 CD23.

189 Similar to the disruptive IgE inhibitor DARPin ${ }^{\circledR}$ E2 79 , the bivalent anti-IgE/ anti-HSA 190 Nanobody ${ }^{\circledR}$ ALX-0962 has been reported to neutralize free IgE and remove FcERI191 bound $\lg E$ from human primary basophils [50]. In various studies, it has been

192 speculated that disruptive inhibitors might show faster onset of action compared to conventional anti-IgE molecules and thereby accelerate treatment benefits.

\section{Conclusions}

196 In summary, we have highlighted various anti-IgE approaches to interfere with the 197 allergic cascade on multiple levels (Figure 2a). While the neutralization of free serum IgE represents the oldest and most advanced therapeutic strategy, recent studies have paved the way for alternative treatment approaches. Targeting of IgE producing B-cells has gained a lot of momentum. However, it is most likely due to the low frequency, the

201 short half-live and the anatomic location of $\operatorname{IgE}$ bearing B-cells that this strategy has

202 shown limited success in clinical trials so far. Disruptive IgE inhibitors that in addition 203 to the neutralization of free IgE actively desensitize antigen-presenting or allergic 204 effector cells are the most recent development in the anti-IgE field. It will be interesting 205 to see whether and how this additional mode of action might translate into patient 206 benefit. The development of a molecule that efficiently targets the allergic cascade at 
207 multiple levels and unifies different modes of action (Figure $\mathbf{2 b}$ ) might be an attractive 208 way to improve the treatment efficacy for allergic disorders in the future. 
Gasser et al.

210 Table 1.

\begin{tabular}{|c|c|c|c|c|c|c|}
\hline & Omalizumab & Ligelizumab & MEDI4212 & Quilizumab & bi53_79 & 026 sdab \\
\hline Class & $\lg G 1 \kappa$ & $\lg G 1 \kappa$ & $\lg G 1 \lambda$ & $\lg G 1 \kappa$ & DARPin* & $\begin{array}{l}\text { single-domain } \\
\text { antibody }\end{array}$ \\
\hline $\begin{array}{l}\text { Affinity constant } K_{D} \\
\text { [M] }\end{array}$ & $7 \times 10^{-9} \mathrm{M}$ & $1.4 \times 10^{-10} \mathrm{M}$ & $2 \times 10^{-12} \mathrm{M}$ & $?$ & $12 \times 10^{-9} \mathrm{M}$ & $1.4 \times 10^{-9} \mathrm{M}$ \\
\hline Free IgE binding & + & ++ & +++ & - & + & + \\
\hline $\begin{array}{l}\text { IgE:FceRla complex } \\
\text { disruption }\end{array}$ & + & $?$ & $?$ & - & +++ & ++ \\
\hline FceRla inhibition & + & ++ & +++ & - & + & + \\
\hline CD23 inhibition & + & $?$ & + & - & + & + \\
\hline $\begin{array}{l}\operatorname{lgE}^{+} \text {B-cells } \\
\text { elimination }\end{array}$ & - & $?$ & + & + & $?$ & $?$ \\
\hline References & {$[25,33,34,47]$} & {$[30,36]$} & {$[37,38,44]$} & [40-43] & {$[33,46,47]$} & [49] \\
\hline
\end{tabular}

211

212

* DARPin = Designed Ankyrin Repeat Protein; + = positive evidence; - = negative evidence; ? = unknown 


\section{$213 \quad$ Figure Legends}

Figure 1. Structural representations of IgE-Fc variants alone or in complex with

the indicated receptors or anti-IgE molecules. The two IgE-Fc heavy chains are represented in yellow and black, while $\lg E$ receptors and anti-IgE molecules are

218 colored in red or red/orange. (a) Asymmetrically bent conformation of IgE-Fc $\mathrm{C}_{2-4}, \mathrm{PDB}$ ID: 1O0V; (b) Complexed FcERla:IgE-Fc $3-4$, PDB-ID: 1F6A; (c) Open conformation of IgE-Fc $3-4$, PDB-ID: $3 \mathrm{HA0}$;

(d) Complexed FceRla:IgE-Fc $2-4$, PDB-ID: 2Y7Q;

221 Complexed CD23:IgE-Fc $c_{3-4}$, PDB-ID: 4EZM; (f) Closed conformation of IgE-Fc $\mathrm{C}_{3-4}$, PDB-ID: 3H9Z; (g) Complexed Omalizumab Fab:IgE-G335C-Fc $\mathrm{C}_{3-4}$, PDB-ID: 5HYS; (h)

223 Complexed MEDI4212:IgE-Fc $3-4$, PDB-ID: 5ANM. Structure is vertically turned $90^{\circ}$ to 224 the left compared to all other images; (i) Complexed DARPin E2_79:IgE-Fc $c_{3-4}$, PDBID: 4GRG; (j) Complexed FabXol3:IgE-Fc $2-4$, PDB-ID: 5G64; (k) Complexed 026 sdab:IgE-Fc $3-4$, PDB-ID: 5NQW.

Figure 2. Anti-IgE intervention strategies. During allergic sensitization, activated isotype switched $B$-cells $(B)$ produce allergen-specific $\lg E$, which is released into the circulation. Soluble free IgE may bind to the low affinity lgE-receptor CD23 expressed on B-cells or to the high affinity lgE-receptor FcERla expressed on allergic effector cells such as basophils (Ba) in the blood. (a) The primary mode of action for the anti-lgE antibodies Omalizumab, Ligelizumab and MEDI4212 is the neutralization and 234 clearance of soluble IgE (red solid lines). Omalizumab and MEDI4212 also inhibit 235 binding of $\operatorname{IgE}$ to CD23 (dashed lines). Further, Omalizumab accelerates the 236 dissociation of IgE from FceRla (dashed line), while the afucosylated version of 237 MEDI4212 aims to target and eliminate $\lg ^{+}$B-cells. Quilizumab targets the membrane 238 proximal $\mathrm{M} 1$ domain on $\lg ^{+} \mathrm{B}$-cells and eliminates these cells by ADCC; black star: 
239 improved FcyRIIA binding. (b) We propose, that an anti-lgE molecule which interferes

240 with the allergic cascade at multiple levels would achieve maximal therapeutic efficacy.

241 Ideally, such a molecule would neutralize soluble $\operatorname{lgE}$, actively dissociate pre-formed

242 IgE:FceRla complexes on the surface of sensitized allergic effector cells and target

243 IgE-producing B-cells to inhibit IgE-synthesis. 
References

246 1. Platts-Mills TAE, Heymann PW, Commins SP, Woodfolk JA: The discovery of

247 IgE 50 years later. Ann Allergy Asthma Immunol 2016, 116:179-182.

248 2. Johansson SGO: The discovery of IgE. J Allergy Clin Immunol 2016,

$249 \quad 137: 1671-1673$.

250 3. Mukai K, Tsai M, StarkI P, Marichal T, Galli SJ: IgE and mast cells in host defense against parasites and venoms. Semin Immunopathol 2016, 38:581603.

- $\quad$ This review gives an overview about the protective role of mast cells and IgE against parasite infections and venoms.

4. Gould HJ, Sutton BJ: IgE in allergy and asthma today. Nat Rev Immunol 2008, 8:205-217.

5. Sullivan SD, Turk F: An evaluation of the cost-effectiveness of omalizumab for the treatment of severe allergic asthma. Allergy 2008, 63:670-684.

6. Muraro A, Werfel T, Hoffmann-Sommergruber K, Roberts G, Beyer K, Bindslev-Jensen C, Cardona V, Dubois A, duToit G, Eigenmann P, et al.: EAACI food allergy and anaphylaxis guidelines: diagnosis and management of food allergy. Allergy 2014, 69:1008-1025.

7. Wan T, Beavil RL, Fabiane SM, Beavil AJ, Sohi MK, Keown M, Young RJ, Henry AJ, Owens RJ, Gould HJ, et al.: The crystal structure of IgE Fc reveals an asymmetrically bent conformation. Nat Immunol 2002, 3:681686.

8. Dhaliwal B, Yuan D, Pang MOY, Henry AJ, Cain K, Oxbrow A, Fabiane SM,

Beavil AJ, McDonnell JM, Gould HJ, et al.: Crystal structure of IgE bound to its $B$-cell receptor CD23 reveals a mechanism of reciprocal allosteric inhibition with high affinity receptor Fc\{varepsilon\}RI. Proceedings of the National Academy of Sciences 2012, 109:12686-12691.

9. Greer AM, Wu N, Putnam AL, Woodruff PG, Wolters P, Kinet J-P, Shin J-S: Serum IgE clearance is facilitated by human FceRI internalization. $J$ Clin Invest 2014, 124:1187-1198.

10. Garman SC, Wurzburg BA, Tarchevskaya SS, Kinet JP, Jardetzky TS: Structure of the Fc fragment of human IgE bound to its high-affinity receptor Fc epsilonRI alpha. Nature 2000, 406:259-266.

11. Holdom MD, Davies AM, Nettleship JE, Bagby SC, Dhaliwal B, Girardi E, Hunt J, Gould HJ, Beavil AJ, McDonnell JM, et al.: Conformational changes in IgE contribute to its uniquely slow dissociation rate from receptor FcERI. Nat. Struct. Mol. Biol. 2011, 18:571-576.

12. Wurzburg BA, Garman SC, Jardetzky TS: Structure of the human IgE-Fc C epsilon 3-C epsilon 4 reveals conformational flexibility in the antibody effector domains. Immunity $2000,13: 375-385$. 
13. McDonnell JM, Calvert R, Beavil RL, Beavil AJ, Henry AJ, Sutton BJ, Gould HJ, Cowburn D: The structure of the IgE Cepsilon2 domain and its role in stabilizing the complex with its high-affinity receptor FcepsilonRlalpha. Nat Struct Biol 2001, 8:437-441.

14. Galli SJ, Tsai M, Piliponsky AM: The development of allergic inflammation. Nature 2008, 454:445-454.

15. Zelensky AN, Gready JE: The C-type lectin-like domain superfamily. FEBS J. 2005, 272:6179-6217.

16. Epp A, Sullivan KC, Herr AB, Strait RT: Immunoglobulin Glycosylation Effects in Allergy and Immunity. Curr Allergy Asthma Rep 2016, 16:79.

17. Shade K-TC, Platzer B, Washburn N, Mani V, Bartsch YC, Conroy M, Pagan $\mathrm{JD}$, Bosques $\mathrm{C}$, Mempel TR, Fiebiger $\mathrm{E}$, et al.: A single glycan on IgE is indispensable for initiation of anaphylaxis. J Exp Med 2015, 212:457-467.

- $\quad$ This study emphasizes the importance of IgE glycosylation for its interaction with the high affinity receptor FceRla.

18. Hibbert RG, Teriete P, Grundy GJ, Beavil RL, Reljic R, Holers VM, Hannan JP, Sutton BJ, Gould HJ, McDonnell JM: The structure of human CD23 and its interactions with IgE and CD21. J Exp Med 2005, 202:751-760.

19. Yuan D, Keeble AH, Hibbert RG, Fabiane S, Gould HJ, McDonnell JM, Beavil AJ, Sutton BJ, Dhaliwal B: Ca2+-dependent structural changes in the B-cell receptor CD23 increase its affinity for human immunoglobulin E. Journal of Biological Chemistry 2013, 288:21667-21677.

20. Wurzburg BA, Tarchevskaya SS, Jardetzky TS: Structural changes in the lectin domain of $C D 23$, the low-affinity IgE receptor, upon calcium binding. Structure 2006, 14:1049-1058.

21. Dhaliwal B, Pang MOY, Keeble AH, James LK, Gould HJ, McDonnell JM, Sutton BJ, Beavil AJ: IgE binds asymmetrically to its $B$ cell receptor CD23. Sci Rep 2017, 7:45533.

- $\quad$ This study reports a two-state binding model for the IgE:CD23 interaction.

22. Selb R, Eckl-Dorna J, Twaroch TE, Lupinek C, Teufelberger A, Hofer G, Focke-Tejkl M, Gepp B, Linhart B, Breiteneder H, et al.: Critical and direct involvement of the CD23 stalk region in IgE binding. J Allergy Clin Immunol 2017, 139:281-289.e5.

23. Liu C, Richard K, Wiggins M, Zhu X, Conrad DH, Song W: CD23 can negatively regulate B-cell receptor signaling. Sci Rep 2016, 6:25629.

24. Engeroff $P$, Fellmann $M$, Yerly D, Bachmann MF, Vogel M: A novel recycling mechanism of native IgE-antigen complexes in human $B$ cells facilitates transfer of antigen to dendritic cells for antigen presentation. J Allergy Clin Immunol 2017, doi:10.1016/j.jaci.2017.09.024. 
324 - This study reports a new role of B cells in recycling functional allergen:IgE complexes in a CD23-dependent manner.

25. Busse W, Corren J, Lanier BQ, McAlary M, Fowler-Taylor A, Cioppa GD, van As $A$, Gupta N: Omalizumab, anti-IgE recombinant humanized monoclonal antibody, for the treatment of severe allergic asthma. Journal of allergy and clinical immunology 2001, 108:184-190.

26. Chipps BE, Lanier B, Milgrom H, Deschildre A, Hedlin G, Szefler SJ, Kattan M, Kianifard $F$, Ortiz B, Haselkorn T, et al.: Omalizumab in children with uncontrolled allergic asthma: Review of clinical trial and real-world experience. J Allergy Clin Immunol 2017, 139:1431-1444.

27. Maurer M, Rosén K, Hsieh H-J, Saini S, Grattan C, Gimenéz-Arnau A, Agarwal S, Doyle R, Canvin J, Kaplan A, et al.: Omalizumab for the Treatment of Chronic Idiopathic or Spontaneous Urticaria. N Engl J Med 2013, 368:924935.

28. MacGinnitie AJ, Rachid R, Gragg H, Little SV, Lakin P, Cianferoni A, Heimall J, Makhija M, Robison R, Chinthrajah RS, et al.: Omalizumab facilitates rapid oral desensitization for peanut allergy. J Allergy Clin Immunol 2017, 139:873-881.e8.

29. Dantzer JA, Wood RA: The use of omalizumab in allergen immunotherapy. Clin Exp Allergy 2018, 48:232-240.

30. Arm JP, Bottoli I, Skerjanec A, Floch D, Groenewegen A, Maahs S, Owen CE, Jones I, Lowe PJ: Pharmacokinetics, pharmacodynamics and safety of QGE031 (ligelizumab), a novel high-affinity anti-IgE antibody, in atopic subjects. Clin Exp Allergy 2014, 44:1371-1385.

31. Holgate S, Buhl R, Bousquet J, Smith N, Panahloo Z, Jimenez P: The use of omalizumab in the treatment of severe allergic asthma: A clinical experience update. Respir Med 2009, 103:1098-1113.

32. Hill DA, Siracusa MC, Ruymann KR, Tait Wojno ED, Artis D, Spergel JM: Omalizumab therapy is associated with reduced circulating basophil populations in asthmatic children. Allergy 2014, 69:674-677.

33. Pennington LF, Tarchevskaya S, Brigger D, Sathiyamoorthy K, Graham MT, Nadeau KC, Eggel A, Jardetzky TS: Structural basis of omalizumab therapy and omalizumab-mediated IgE exchange. Nat Commun 2016, 7:11610-12.

-• This study presents a high-resolution crystal structure of the Omalizumab:lgEFc complex and sheds new light on the mode of action of Omalizumab.

34. Davies AM, Allan EG, Keeble AH, Delgado J, Cossins BP, Mitropoulou AN, Pang MOY, Ceska T, Beavil AJ, Craggs G, et al.: Allosteric mechanism of action of the therapeutic anti-IgE antibody omalizumab. Journal of Biological Chemistry 2017, doi:10.1074/jbc.M117.776476.

35. Selb R, Eckl-Dorna J, Neunkirchner A, Schmetterer K, Marth K, Gamper J, Jahn-Schmid B, PickI WF, Valenta R, Niederberger V: CD23 surface density 
on B cells is associated with IgE levels and determines IgE-facilitated allergen uptake, as well as activation of allergen-specific T cells. J Allergy Clin Immunol 2017, 139:290-299.e4.

36. Gauvreau GM, Arm JP, Boulet L-P, Leigh R, Cockcroft DW, Davis BE, Mayers I, Fitzgerald JM, Dahlén B, Killian KJ, et al.: Efficacy and safety of multiple doses of QGE031 (ligelizumab) versus omalizumab and placebo in inhibiting allergen-induced early asthmatic responses. $J$ Allergy Clin Immunol 2016, 138:1051-1059.

- $\quad$ This study compares the efficacy of Omalizumab and Ligelizumab in vivo.

37. Cohen ES, Dobson CL, Käck H, Wang B, Sims DA, Lloyd CO, England E, Rees DG, Guo H, Karagiannis SN, et al.: A novel IgE-neutralizing antibody for the treatment of severe uncontrolled asthma. MAbs 2014, 6:756-764.

38. Sheldon E, Schwickart M, Li J, Kim K, Crouch S, Parveen S, Kell C, Birrell C: Pharmacokinetics, Pharmacodynamics, and Safety of MEDI4212, an AntiIgE Monoclonal Antibody, in Subjects with Atopy: A Phase I Study. Adv Ther 2016, 33:1-27.

39. Nemazee D: Mechanisms of central tolerance for B cells. Nat Rev Immunol 2017, 17:281-294.

40. Brightbill HD, Jeet S, Lin Z, Yan D, Zhou M, Tan M, Nguyen A, Yeh S, Delarosa $D$, Leong $S R$, et al.: Antibodies specific for a segment of human membrane IgE deplete IgE-producing B cells in humanized mice. J Clin Invest 2010, 120:2218-2229.

41. Gauvreau GM, Harris JM, Boulet L-P, Scheerens H, Fitzgerald JM, Putnam WS, Cockcroft DW, Davis BE, Leigh R, Zheng Y, et al.: Targeting membraneexpressed IgE $B$ cell receptor with an antibody to the M1 prime epitope reduces IgE production. Sci Transl Med 2014, 6:243ra85-243ra85.

42. Harris JM, Maciuca R, Bradley MS, Cabanski CR, Scheerens H, Lim J, Cai F, Kishnani M, Liao XC, Samineni D, et al:: A randomized trial of the efficacy and safety of quilizumab in adults with inadequately controlled allergic asthma. Respir. Res. 2016, 17:29.

43. Harris JM, Cabanski CR, Scheerens H, Samineni D, Bradley MS, Cochran C, Staubach $P$, Metz M, Sussman G, Maurer M: A randomized trial of quilizumab in adults with refractory chronic spontaneous urticaria. $J$ Allergy Clin Immunol 2016, 138:1730-1732.

44. Nyborg AC, Zacco A, Ettinger R, Jack Borrok M, Zhu J, Martin T, Woods R, Kiefer C, Bowen MA, Suzanne Cohen E, et al.: Development of an antibody that neutralizes soluble IgE and eliminates IgE expressing B cells. Cell. Mol. Immunol. 2015, 13:391-400.

45. Baumann MJ, Eggel A, Amstutz P, Stadler BM, Vogel M: DARPins against a functional IgE epitope. Immunol Lett 2010, 133:78-84.

46. Kim B, Eggel A, Tarchevskaya SS, Vogel M, Prinz H, Jardetzky TS: 
Accelerated disassembly of IgE-receptor complexes by a disruptive macromolecular inhibitor. Nature 2012, doi:10.1038/nature11546.

47. Eggel A, Baravalle G, Hobi G, Kim B, Buschor P, Forrer P, Shin J-S, Vogel M, Stadler BM, Dahinden CA, et al.: Accelerated dissociation of IgE-FceRI complexes by disruptive inhibitors actively desensitizes allergic effector cells. J Allergy Clin Immunol 2014, doi:10.1016/j.jaci.2014.02.005.

48. Prinz $\mathrm{H}$, Striessnig J: Ligand-induced accelerated dissociation of (+)-cisdiltiazem from L-type Ca2+ channels is simply explained by competition for individual attachment points. J Biol Chem 1993, 268:18580-18585.

49. Jabs F, Plum M, Laursen NS, Jensen RK, Mølgaard B, Miehe M, Mandolesi M, Rauber MM, Pfützner W, Jakob T, et al.: Trapping IgE in a closed conformation by mimicking CD23 binding prevents and disrupts FceRI interaction. Nat Commun 2018, 9:7.

- $\quad$ This study reports an interesting disruptive IgE inhibitor that exerts its function via allosteric inhibition.

50. Rinaldi M, Denayer T, Thiolloy S, Tosar LCP, Buyse M-A, De Decker P, De Witte E, Meerts P, Baumeister J, Holz J-B: ALX-0962, an anti-IgE Nanobody ${ }^{\circledR}$ with a dual mode of action. Eur Respir J 2013, 42:1765. 


\section{Acknowledgements}

428 We thank all members of the Eggel Lab for their valuable input. This research has been 429 supported by a grant from the Fondation Acteria to A.E., a Swiss National Science 430 Foundation Ambizione grant to A.E. (PZO0P3_148185), a grant from the Lungenliga 431 Bern and a grant from the Lungenliga Schweiz to A.E. 
Figure 1.

(a)

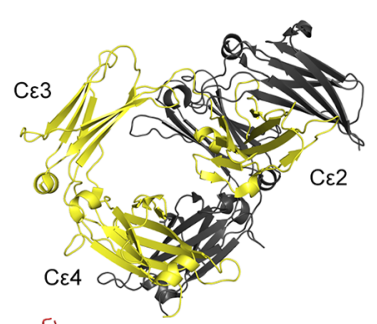

(d)

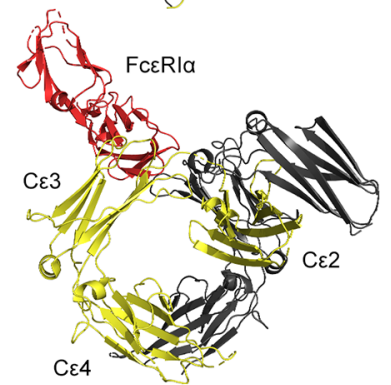

(g) Omalizumab

Omalizumab

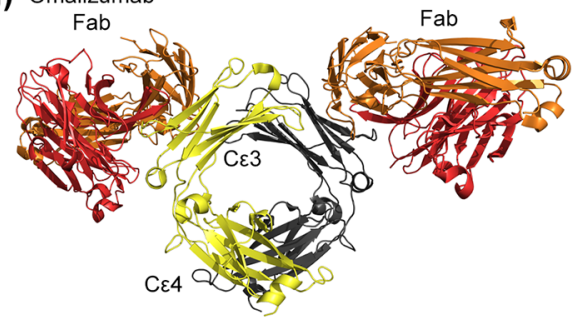

(j)

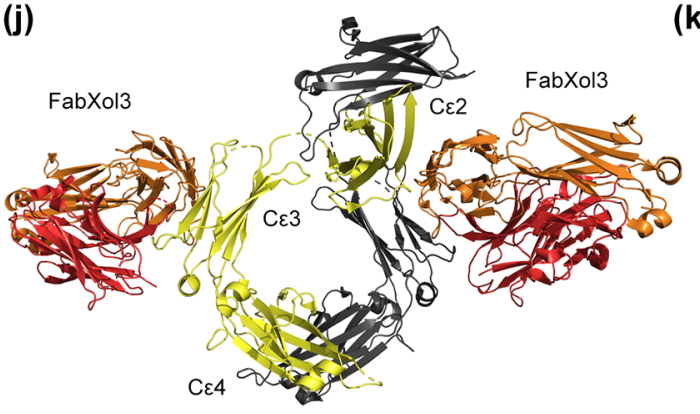

(b)

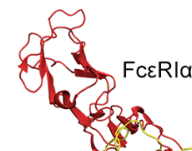

(e)

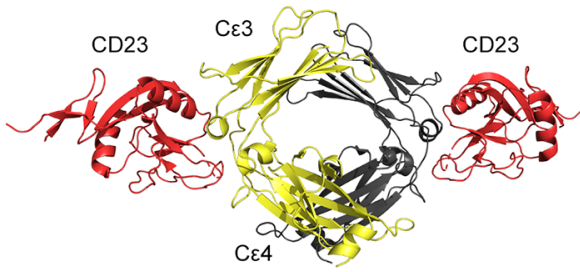

(h)
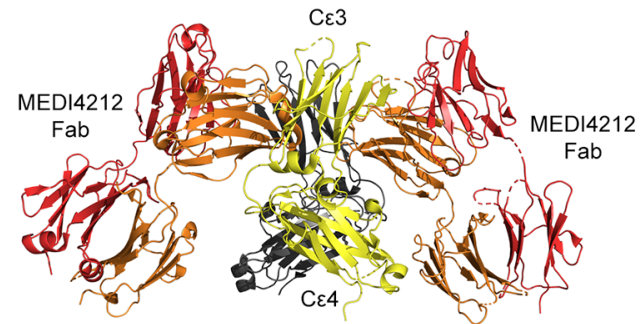

(k) (c)

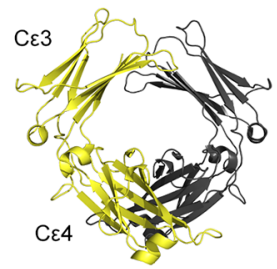

(f)

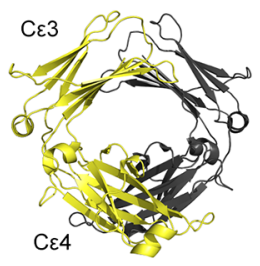

(i)

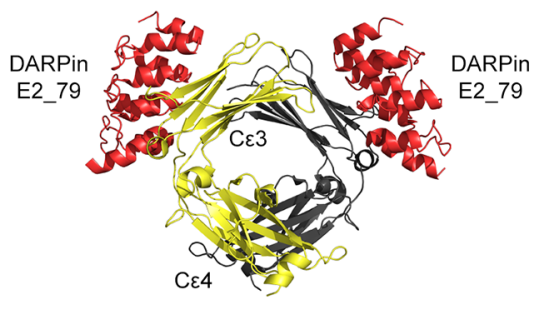

Figure 2.

(a)

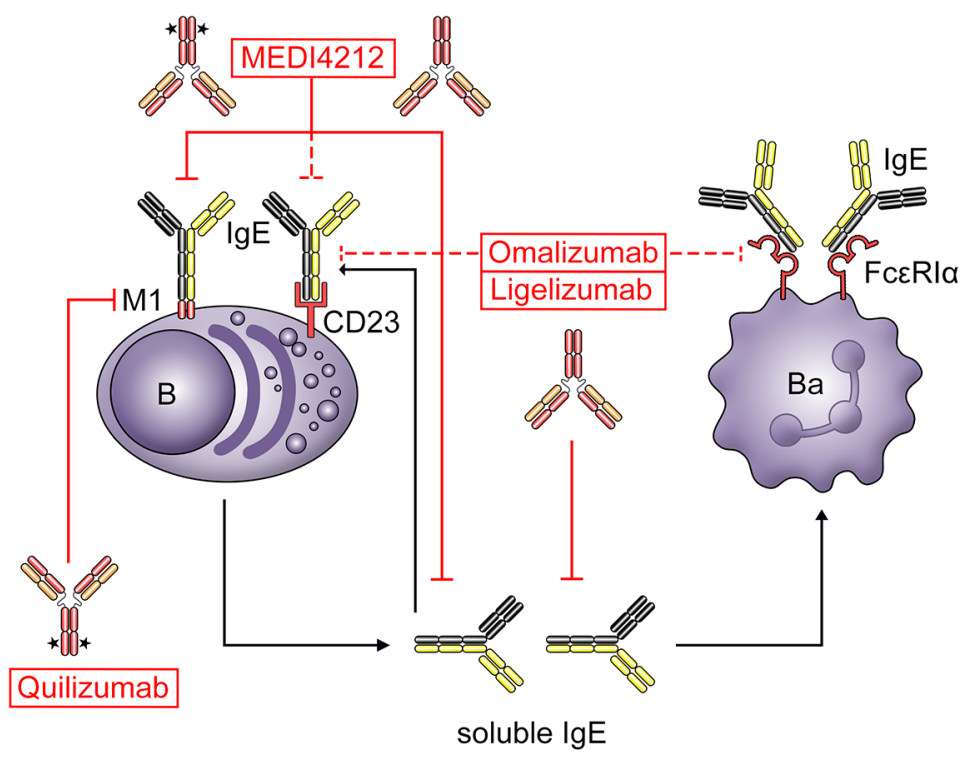

(b)

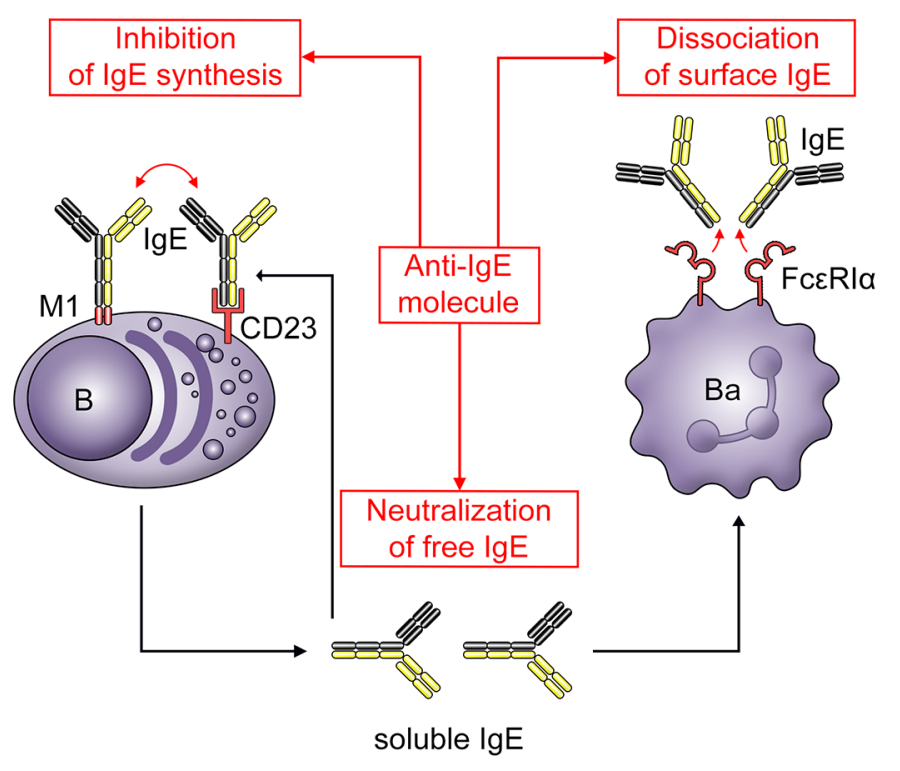

